\title{
EKSISTENSI KOMPILASI HUKUM ISLAM DI INDONESIA
}

\section{Edi Gunawan ${ }^{1}$}

\begin{abstract}
Abstrak
Sejak Kompilasi Hukum Islam tersusun, para penyusunnya tidak secara tegas memberikan pengertian dari Kompilasi Hukum Islam itu sendiri, mereka mempelajari rencana dan proses penyusunannya, sehingga menyatakan bahwa Kompilasi Hukum Islam merupakan rangkuman dari berbagai pendapat hukum yang diambil dari berbagai kitab yang ditulis oleh ulama fikih yang biasa dipergunakan sebagai referensi pada Pengadilan Agama untuk diolah dan dikembangkan serta dihimpun ke dalam satu himpunan yang disebut dengan kompilasi. Kehadiran Kompilasi Hukum Islam (KHI) merupakan rangkaian sejarah hukum masional yang dapat mengungkapkan ragam makna kehidupan masyarakat Islam Indonesia. Kompilasi Hukum Islam dijadikan sebagai pedoman dalam penyelesaian perkara yang diajukan ke pengadilan dalam lingkungan Peradilan Agama. Hal itu disebabkan karena latarbelakang penyusunan Kompilasi Hukum Islam adalah untuk mengisi kekosongan hukum substansial yang dijadikan rujukan dalam penyelesaian perkara yang diajukan ke Peradilan Agama. Namun demikian hakim memiliki kebebasan untuk berkreasi sepanjang hakim tidak menemukan rujukan dalam hukum tertulis.
\end{abstract}

Kata Kunci : Eksistensi, Kompilasi, Hukum Islam

\section{Pendahuluan}

Sudah umum kita ketahui bahwa eksistensi hukum Islam di Indonesia selalu mengambil dua bentuk, yakni hukum normatif yang diimplementasikan secara sadar oleh umat Islam, dan hukum formal yang dilegislasikan sebagai hukum positif bagi umat Islam. Yang pertama menggunakan pendekatan kultural, sementara yang kedua menggunakan penghampiran struktural. Hukum Islam dalam bentuk kedua itu pun prcses legislasinya menggunakan dua cara. Pertama, hukum Islam dilegislasikan secara formal untuk umat Islam, seperti PP Nomor 28 Tahun 1977 tentang Perwakafan, UU Nomor 17 Tahun 1999 tentang Penyelenggaraan Ibadah Haji, dan UU Nomor 38 Tahun 1999 tentang Pengelolaan Zakat. Kedua, materi-materi hukum Islam diintegrasikan ke dalam hukum nasional tanpa menyudutkan hukum Islam secara formal, seperti UU Nomor 1 Tahun 1974 tentang Perkawinan dan UU Nomor 3 tahun 2006 tentang Peradilan Agama.

\footnotetext{
${ }^{1}$ Penulis adalah dosen pada Jurusan Syari’ah STAIN Manado.
} 
Membicarakan tentang masalah Kompilasi Hukum Islam pada dasarnya adalah membicarakan salah satu aspek dari hukum Islam di Indonesia dan bilamana kita membicarakan tentang hukum Islam di Indonesia, kita akan memasuki sebuah perbincangan yang kompleks ${ }^{2}$ sekalipun hukum Islam menempati posisi yang sangat penting dalam kehidupan berbangsa dan bernegara pada masa sekarang.

Secara garis besar bahwa buku tentang Kompilasi Hukum Islam terdiri dari tiga buku masing-masing buku pertama tentang perkawinan (Munakahat), buku kedua tentang kewairsan (Faraid) dan buku ketiga adalah perwakafan. Dalam kerangka sistematikanya masing-masing buku terbagi dalam beberapa bab dan kemudian untuk bab-bab tertentu terbagi pula atas beberapa bagian yang selanjutnya dirinci dalam pasal-pasal.

Menurut Hasballah Thaib ${ }^{3}$ mengatakan pembaharuan Hukum Islam di Indonesia agak lamban perkembangannya dibandingkan dengan negara-negara Islam di Tmur Tengah dan Afrika Utara. Keterlamabatan ini disebabkan oleh beberapa faktor; pertama, masih kuat anggapan bahwa taqlid $^{4}$ masih cukup untuk menjawab persoalan-persoalan kontemporer, di samping banyak ulama merasa lebih mengikuti pendapat ulama terdahulu daripada mengikuti pendapat orang banyak, tetapi was-was untuk salah. Kedua hukum Islam di Indonesia dalam konteks sosial politik masa kini selalu mengundang polemik berada pada titik tengah antara paradigma agama dan paradigma negara. Bila dianggap sebagai paradigma negara, hukum Islam harus siap mengahadapi masyarakat yang plural, ketiga Persepsi sebagian masyarakat yang mengindetikkan fiqih sebagai hasil kerja intelektual agama yang kebenarannya relatif dengan syariat yang merupakan produk Allah dan bersifat absolut.

${ }^{2}$ Persoalannya dikatakan bersifat sangat kompleks adalah oleh karena:

a. berlakunya hukum Islam di Indonesia untuk sebagian besar adalah tergantung pada umat Islam yang menjadi pendukung utamanya.

b. Sekalipun hukum Islam sudah dilaksanakan di Indonesia dalam kehidupan umatnya sudah lebih dari ribuan tahun namun hukum Islam Indonesia masih belum memperlihatkan bentuknya yang utuh sesuai dengan konsep dasarnya menurut Alquran dan Sunnah.

c. Hukum Islam dengan gaya lenturnya (adabtability) yang tinggi senantiasa berpacu dengan perkembangankemajuan zaman.(Lihat Abdurrahman, Kompilasi Hukum Islam di Indonesia, (Cet. III; Jakarta: CV. Akademika Pressindo, 2001), h. 1-2

${ }^{3}$ Lihat Hasballah Thaib, Tajdid Reaktualisasi dan Elastisitas Hukum Islam. Makalah disampaikan pada acara seminar para hakim dan panitera Peradilan Agama se-Sumatra Utara di Medan tanggal 12 Juni 2002, h. 12

${ }^{4}$ Taqlid adalah menerima atau mengikuti pendapat orang lain (mujtahid/ulama) tanpa mengetahui di atas dasar apa pendapat demikian ditegakkan. Orang yang melakukan taqlid disebut muqallid. Tidak semua bertaqlid itu dibenarkan atau dipersalahkan. Orang yang mampu berijtihad (memenuhi ijtihad ) tentu tidak dibenarkan bertaqlid kepada orang (ulama) lain, sedang bagi mereka yang tidak mampu berijtihad sendiri dibenarkan bertaqlid kepada mujtahid/ulama yang diyakini kebenaran pendapatnya, bahkan wajib. Lihat M. Abdul Mujieb dkk, Kamus Istilah Fiqih, ( Cet. I; Jakarta: PT. Pustaka Firdaus, 1994), h. 369. 
Kewarisan sebagai suatu bagian hukum Islam menjadi salah satu bahasan pokok dalam Kompilasi Hukum Islam. Dalam UU No. 7 tahun 1989 tentang Peradilan Agama pasal 49 ayat 1 huruf $b$ diatur tentang penentuan siapa-siapa yang menjadi ahli waris, penentuan mengenai harta peninggalan, penentuan bagian masing-masing ahli waris dan melaksanakan pembagian harta peninggalan tersebut. ${ }^{5}$

\section{Pembahasan}

\section{Latar Belakang Penyusunan KHI}

Ungkapan bahwa UUD 1945 merupakan hukum dasar yang tertulis, di samping berlaku juga hukum dasar yang tidak tertulis yang dijumpai dalam penjelasan umumnya menjadi dasar konstitusional dan sinyal organik keberadaan hukum tidak tertulis dalam tata hukum nasional. Norma dasar dalam pasal II aturan Peralihan UUD 1945 menunjukkan hukum yang menjadi isi awal $^{6}$ tata hukum nasional dengan menyatakan segala peraturan yang ada ${ }^{7}$ masih langsung berlaku selama belum diadakan yang baru menurut $\mathrm{UUD}^{8}$.

KHI disusun atas prakarsa penguasa Negara, dalam hal ini Ketua Mahkamah Agung dan Menteri Agama (melalui Surat Keputusan Bersama) dan mendapat pengakuan ulama dari berbagai unsur. Secara resmi Kompilasi Hukum Islam merupakan hasil konsensus (ijma') ulama dari berbagai golongan melalui media lokakarya yang dilaksanakan secara nasional, yang kemudian mendapat legalisasi dari kekuasaan negara 9 .

Peyusunan KHI dapat dipandang sebagai suatu proses transformasi hukum Islam dalam bentuk tidak tertulis ke dalam peraturan perundang-undangan. Dalam penyusunannya dapat dirinci pada dua tahapan. Pertama, tahapan pengumpulan bahan baku, yang digali dari berbagai sumber baik tertulis maupun tidak tertulis. Kedua, tahapan perumusan yang didasarkan kepada peraturan perundang-undangan yang berlaku dan sumber hukum Islam (Alquran dan Sunnah),

\footnotetext{
${ }^{5}$ Roihan A. Rasyid, hukum Acara Peradilan Agama, (Cet. VIII; Jakarta: PT Raja Grafindo Persada, 2001)., h. 33 .

${ }^{6}$ Naskah Proklamasi Kemerdekaan Republik Indonesia yang dibacakan pada tanggal 17 Agustus 1945 merupakan norma pertama dalam hukum nasional serta yang melahirkan tata hukum legislative nasional seperti terumus dalam naskah UU 1945 yang ditetapkan pada tanggal 18 Agustus 1945.

${ }^{7}$ Yang dimaksud adalah sekitar peraturannya tanpa ikut sertanya sistem tata hukum kolonial, karena sistem itu telah dijebol oleh jiwa dan semangat naskah Proklamasi Kemerdekaan, dan di sanalah letak perbedaannya dengan peraturan hukum adat dan hukum Islam yang lahir secara normatif dalam sejarah masyarakat Indonesia.

${ }^{8}$ Abdul Gani Abdullah, Pengantar Kompilasi Hukum Islam dalam Tata Hukum Indonesia, (Cet. I; Jakarta: Gema Insani Press, 1994). h. 58.

${ }^{9}$ Cik Hasan Bisri, Kompilasi Hukum Islam dalam Sistem Hukum Nasional,( Cet. I; Jakarta: PT. Logos Wacana Ilmu, 1999), h. 8
} 
khusunya ayat yang teksnya berhubungan dengan substansi KHI. Dalam penyusunan KHI, secara substansial dilakukan dengan mengacu kepada sumber hukum Islam yakni Alquran dan Sunnah, dan secara hirarkial mengacu kepada peraturan perundang-undangan yang berlaku ${ }^{10}$.

Dari sudut lingkup the ideal law, kehadiran Kompilasi Hukum Islam merupakan rangkaian sejarah hukum nasional yang dapat mengungkapkan ragam makna kehidupan masyarakat Islam Indonesia, terutama tentang: (1) adanya norma hukum yang hidup dan ikut serta bahkan mengatur interaksi sosial, ${ }^{11}$ (2) aktualnya dimensi normatif akibat terjadinya eksplanasi fungsional ajaran Islam yang mendorong terpenuhinya tuntutan kebutuhan hukum, (3) responsi struktural yang dini melahirkan rangsangan KHI, dan (4) alim ulama Indonesia mengantisipasi ketiga hal di atas dengan kesepakatan bahwa KHI adalah rumusan tertulis hukum Islam yang hidup seiring dengan kondisi hukum dan masyarakat Indonesia. ${ }^{12}$

Berkenaan dengan kedudukan KHI dalam sistem hukum nasional, diukur oleh unsurunsur sistem hukum nasional sebagaimana telah dikemukakan. Pertama, landasan ideal dan konstitusional KHI adalah Pancasila dan UUD 1945. hal itu dimuat dalam konsiderans Instruksi Presiden dan dalam penjelasan umum KHI. Ia disusun sebagai bagian dari sistem hukum nasional yang menjamin kelangsungan hidup beragama berdasarkan Ketuhanan Yang Maha Esa yang sekaligus merupakan perwujudan kesadaran hukum masyarakat dan bangsa Indonesia. Kedua, ia dilegalisasi oleh instrument hukum dalam bentuk Instruksi Presiden yang dilaksanakan oleh Keputusan Menteri Agama, yag merupakan bagian dari rangkaian peraturan perundang-undangan yang berlaku. Ketiga, ia dirumuskan dari tatanan hukum Islam yang bersumber dari Alquran dan Sunnah Rasul. Hal itu yang menjadi inti hukum Islam yang mencakup berbagai dimensi: syariah, fiqh, fatwa, qanun, idarah, qadha, dan adat. Ia merupakan perwujudan hukum Islam yang bercorak keindonesiaan. Keempat, saluran dalam aktulisasi KHI antara lain pengadilan dalam lingkungan Peradilan Agama, sebagaimana dapat ditafsirkan secara teleologis dari penjelasan umum $\mathrm{KHI}^{13}$. Sumber, legalitas, dan adaptasi dalam pengumpulan bahan dan Perumusan KHI.

\footnotetext{
${ }^{10}$ Ketika KHI disebarluaskan dengan dasar Intruksi Presiden dan keputusan Menteri Agama, Undangundang Nomor 7 Tahun 1989 telah disahkan dan diundangkan. Namun demikian, karena penyusunan rancangan KHI telah disiapkan sebelumnya, maka dalam penjelasan beberapa pasal KHI ditulis: pasal ini diberlakukan setelah berlakukannya Undang-undang Peradilan Agama.

${ }^{11}$ Permasalahan ini menjadi bagian dari pendapat Abdul Gani Abdullah yang disajikan pada Seminar Nasional Pemasyarakatan Inpres No. 1 Tahun 1991 pada Fakultas Syariah Universitas Islam Indonesia di Yogyakarta, pada tanggal 22 Februari 1992. Lihat Abdul Gani Abdullah dalam bukunya Pengantar Kompilasi Hukum Islam dalam Tata Hukum Indonesia.

${ }^{12}$ Abdul Gani Abdullah, op. cit, h. 63

${ }^{13}$ Abdurrahman op. cit, h. 9-10
} 
Kelayakan KHI untuk dijadikan pedoman dalam penyelesaian masalah dalam masyarakat, khusunya dikalangan umat Islam berhubungan timbal balik dengan unsur lainnya. Pertama, unsur KHI sendiri sebagai bagian dari perangkat hukum yang unifikatif. Kedua, unsur aparatur pemerintahan dan pemimpin masyarakat yang menjadi tokoh rujukan. Ketiga, unsur kesadaran hukum masyarakat terutama KHI. Keempat, unsur kemudahan yang dapat diperoleh oleh masyarakat dalam melaksanakan KHI. ${ }^{14}$

Proses penyusunan KHI dilakukan secara partisipatif. Ia disusun dengan melibatkan pejabat pemerintahan, hakim, dan para pemimpin masyarakat (ulama, zu'ama, dan cendekiawan) yang refresentatif. Mereka adalah kelompok pertama yang memiliki tanggung jawab moral untuk mensosialisasikan KHI kepada masyarakat, terutama dikalangan para pengikut mereka. Sosialisasi ini dapat dilakukan dalam bentuk peyampaian informasi dan aksi kemasyarakatan melalui berbagai media yang dapat digunakan. Dengan demikian KHI layak untuk dijadikan rujukan dalam peyelesaian masalah perkawinan, kewarisan, dan perwakafan yang diteladani oleh elite masyarakat itu.

Keberadaan KHI dalam sistem hukum nasional relatif berumur muda. Ia akan dihadapkan kepada berbagai masalah (di samping masalah harapan-harapan), baik dikalangan pemimpin masyarakat maupun dikalangan para pengikut mereka. Masalah pertama adalah sosialisasi KHI kepada warga masyarakat, khususnya dikalangan umat Islam secara umum. Masalah kedua, adalah persepsi dikalangan pemimpin masyarakat terhadap KHI, terutama dikalangan mereka yang tidak terlibat dalam proses penyusunannya, sementara mereka memiliki keterikatan yang ketat terhadap ajaran fuqaha dan memiliki pengaruh yang kuat dikalangan para pengikut mereka. Masalah ketiga adalah kemungkinan terjadi perbenturan antara KHI dengan struktur dan pola budaya masyarakat, khususnya di bidang kewarisan. KHI disusun dan diputuskan oleh elite masyarakat dipusat pemerintahan dan pendidikan, sementara sebagian besar masyarakat bermukim di pedesaan yang terikat dengan tradisi lokal. Masih besar kemungkinan, masyarakat menerima hukum kewarisan Islam secara simbolik, sedangkan substansinya mengacu kepada kaidah lokal yang berlaku secara turun temurun. Pengkajian tentang hal ini sangat tepat untuk dilakukan secara cermat dan interdisipliner ${ }^{15}$. Dengan cara demikian, dapat dilakukan

\footnotetext{
${ }^{14}$ Ibid, h. 15

${ }^{15}$ Dalam penelitian Cik Hasan Bisri dkk (1997) disebuah desa di Kabupaten Sumedang, Jawa Barat, menunjukkan terjadi pergulatan antara hukum kewarisan Islam dipahami dengan pemikiran yang sederhana dan
} 
pelukisjelasan hukum kewarisan itu secara deskriptif. Bertitik tolak dari hasil pengkajian itu, kemudian dapat dilakukan sosialisasi yang tepat pula.

Hukum Islam di Indonesia masa kini adalah merupakan sebuah label yang diberikan pada ketentuan-ketentuan hukum Islam yang berlaku di Indonesia dan sekaligus menampilkan corak khas ke-Indonesiaannya. Sistem dan budaya Indonesia akan lebih terefleksi di dalamnya sehingga hukum Islam dimaksud untuk beberapa bagian tertentu baik yang menyangkut kaidah hukumnya maupun pola pemikiran yang mendasarinya akan menunjukkan beberapa perbedaan dengan Hukum Islam yang berlaku dilain tempat seperti Saudi Arabiah, Mesir, Iran, Pakistan dan lain-lain sekalipun sifat dasar yang sama karena bersumberkan pada sumber yang sama yaitu Alquran dan Sunnah. Mungkin apa yang kita sebut dengan Hukum Islam Indonesia masa kini masih belum terwujud sebagaimana yang kita harapkan bersama atau mungkin juga belum terpolakan dengan jelas, apa yang sekarang kita hadapi dengan diberlakukannya Kompilasi Hukum Islam adalah bagian dari apa yang kita perbincangkan mengenai keberlakuan Hukum Islam di Indonesia.

Kompilasi Hukum Islam dianggap sebagai satu di antara sekian banyak karya ${ }^{16}$ umat Islam Indonesia dalam rangka memberi arti yang lebih positif bagi kehidupan beragamnya dalam rangka kebangkitan umat Islam di Indonesia. Secara tidak langsung ia juga merefleksi tingkat keberhasilan tersebut. Sehingga dengan membaca karya tersebut orang akan dapat memberikan penilaian tingkat kemampuan umat Islam dalam proses pembentukan hukum. Akan tetapi, karena Kompilasi Hukum Islam harus dilihat bukan sebagai sebuah final, maka kita juga dapat melihatnya sebagai salah satu jenjang dalam usaha tersebut dan sekaligus juga menjadi batu loncatan untuk meraih keberhasilan yang lebih baik di masa mendatang.

a. Tujuan Kompilasi.

$>$ Melengkapi pilar Peradilan Agama ${ }^{17}$.

$>$ Menyamakan persepsi penerapan hukum ${ }^{18}$.

dalam konteks kebudayaan lokal, sehingga mengalami bias dan reduksi pemahaman. Hukum kewarisan itu diterima simbolik, sedangkan substansinya berakar pada sutruktur dan pola budaya masyarakat lokal. Ibid, h. 17

${ }^{16}$ Abdurrahman, op. cit, h. 6

${ }^{17}$ Adapun pilar-pilar yang dimaksud adalah: a) adanya badan peradilan yang terorganisir berdasarkan kekuatan Undang-undang. b) adanya organ atau pejabat pelaksana yang berfungsi melaksanakan jalannya peradilan. c) Adanya sarana hukum positif yang pasti dan berlaku secara unifikasi. M. Yahya Harahap, Informasi Materi Kompilasi Hukum Islam: Mempositifkan Abstraksi hukum Islam. (Cet. I; Jakarta: CV. Logos Wacana Ilmu, 1999), h. 28-29

${ }^{18}$ Dengan adanya KHI sebagai kitab hukum, para hakim tidak dibenarkan menjatuhkan putusan-putusan yang berdisparitas. Dengan mempedomani KHI para hakim diharapkan dapat menegakkan hukum dan kepastian 
Mempercepat proses Taqribi Bainal Ummah ${ }^{19}$.

$>$ Menyingkirkan paham Private Affairs ${ }^{20}$.

Sebagai perangkat hukum, KHI telah menampung bagian dari kebutuhan masyarakat di bidang hukum yang digali dari (sumber) nilai-nilai hukum yang diyakini kebenarannya. KHI dapat memberikan perlindungan hukum dan ketentraman batin bagi masyarakat, karena ia menawarkan simbol-simbol keagamaan yang dipandang oleh masyarakat sebagai sesuatu yang sacral. Ia juga mengakomodasi berbagai pandangan dan aliran pemikiran dibidang fiqh yang secara sosiologis memiliki daya pesan dan daya layak untuk dilaksanakan oleh warga masyarakat yang memerlukannya. ${ }^{21}$

Mengenai fungsi KHI, secara singkat KH. Hasan Basry menyebutnya sebagai kompilasi untuk menuju kodifikasi. Dikatakannya pula bahwa Kompilasi Hukum Islam yang kini tengah dicanangkan kalau nanti berhasil dikodifikasikan dan dijadikan Undang-undang/ peraturan oleh pemerintah kita jelas merupakan sumbangan umat Islam yang sangat bagus bagi pembangunan hukum nasional yang selama ini kita dambakan ${ }^{22}$. Berbeda dengan pendapat tersebut Bustanul Arifin mengatakan bahwa kita lakukan adalah kompilasi yaitu mengumpulkan pendapat-pendapat dalam masalah fiqih yang selama ini dianut oleh umat Islam Indonesia. Jadi bukan kodifikasi , sebab istilah ini mengandung arti menciptakan hukum baru atau mengubah yang telah ada ${ }^{23}$.

Dalam penyusunan Kompilasi Hukum Islam pertimbangan-pertimbangan mengenai kemaslahatan amat diperhatikan oleh panitia pembentukan Kompilasi Hukum Islam, terutama mengenai hal-hal berkaitan dalam kategori ijtihad. Dengan begitu diharapkan, selain akan memelihara dan menampung aspirasi hukum serta keadilan masyarakat, kompilasi itu juga akan mampu berperan sebagai perekayasa (social engineering) masyarakat muslim Indonesia. Hal itu itu disebabkan karena masyarakat Indonesia mayoritas menganut agama Islam.

hukum yang seragam tanpa mengurangi kemungkinan terjadinya putusan-putusan yang bercorak variable. Asal tetap proporsional secara kasuistik. Ibid, h. 32

${ }^{19}$ Dengan adanya KHI dapat diharapkan sebagai penyeberangan kearah memperkecil pertentangan dan perbantahan khilafiyah. Ibid, h. 32

${ }^{20}$ Maksudnya menghilangkan pikiran bahwa persoalan tersebut adalah persoalan hukum dan tidak harus diselesaikan secara pribadi karena itu adalah persoalan Negara yang merupakan tanggung jawab aparatur Negara.

${ }^{21}$ Cik Hasan Basri, op. Cit, h. 15.

${ }^{22}$ Hasan Basry, Perlunya Kompilasi Hukum Islam, (Mimbar Ulama No. 104 th. X April 1986), h. 61

${ }^{23}$ Bustanul Arifin, Kompilasi : Fiqih dalam Bahasa Undang-undang, ( Pesantren, No. 2 Vol. II, 1985), h. 28 


\section{Landasan dan Kedudukan KHI}

Sebagaimana kita ketahui, selain kesadaran hukum masyarakat dan penegak hukum yang baik dan benar dalam menjalankan tugasnya, penyelenggaraan hukum di dalam suatu masyarakat dan Negara ditentukan pula oleh kejelasan peraturan hukumnya. Peraturan yang jelas ini selain berguna untuk kepastian hukum, sangat diperlukan dalam penegakan keadilan hukum. Di lingkungan Peradilan Agama di tanah air kita di masa yang lampau, hukum yang diterapkan dalam menyelesaikan suatu perkara tidaklah begitu jelas ${ }^{24}$.

Pada dasarnya, secara substantif, berbagai upaya penghimpunan fikih ke dalam bahasa perudang-undangan telah lama dirintis oleh para ahli hukum dan ulama Indonesia. Kehadiran Undang-undang No. 1 tahun 1974 tentang perkawinan, sebenarnya dapat dilihat sebagai upaya kompilasi, meskipun namanya undang-undang. Undang-undang sendiri memiliki daya ikat dan daya paksa pada subyek dan obyek hukumnya, sementara kompilasi sesuai dengan karakternya, hanyalah menjadi pedoman saja, relatif tidak mengikat. Karena secara yuridis, apabila dilihat dari tertib perundang-undangan TAP MPRS No. XX/MPRS/1966 istilah kompilasi memang tidak termasuk di dalamnya. ${ }^{25}$

Landasan dalam artian sebagai dasar hukum keberadaan Kompilasi Hukum Islam di Indonesia adalah Instruksi Presiden No. 1 tahun 1991 tanggal 10 Juni 1991. Menurut Ismail Suny, oleh karena sudah jelas bahwa dalam bidang perkawinan, kewarisan dan perwakafan bagi pemeluk-pemeluk Islam telah ditetapkan oleh Undang-undang yang berlaku adalah hukum Islam, maka hukum Islam itu yang memuat hukum materilnya dapat ditetapkan oleh Keputusan Presiden/Instruksi Presiden. Pendapat tersebut antara lain didasarkannya pada disertasi dari A. Hamid S. Attamimi. Dan selanjutnya ia mengatakan bahwa Instruksi Presiden tersebut dasar hukumnya adalah pasal 4 ayat 1 Undang-undang dasar 1945, yaitu kekuasaan Presiden untuk memegang kekuasaan pemerintahan Negara. Apakah dinamakan Keputusan Presiden atau Instruksi Presiden, kedudukan hukumnya adalah sama. Oleh karena itu, pembicaraan mengenai

\footnotetext{
${ }^{24} \mathrm{Hal}$ itu disebabkan karena selain terpencar di dalam berbagai kitab fikih yang banyak jumlahnya juga tercantum dalam aneka pendapat yang berbeda. Biro Peradilan Agama yang kini bernama Direktorat Pembinaan Badan Peradilan Agama, dalam Surat Edarannya Nomor 8/I/735 Tahun 1985 menetukan tiga belas kitab fiqih yang menjadi pegangan hakim agama dalam menyelesaikan sengketa yang dimajukan padanya. ( Lihat Muhammad Daud Ali, Hukum Islam, Pengantar Ilmu Hukum dan Tata Hukum Islam di Indonesia, ( Cet. 11; Jakarta: PT. Raja Grafindo Persada, 2004), h. 295.

${ }^{25}$ Ahmad Rafiq, Pembaharuan Hukum Islam di Indonesia (Cet. I; Yogyakarta: Gema Media, 2001), h. 7677.
} 
kedudukan Kompilasi Hukum Islam tidak mungkin dilepaskan dari Instruksi Presiden yang dimaksud ${ }^{26}$.

Instruksi Presiden ini ditujukan kepada Menteri Agama untuk menyebarluaskan Kompilasi Hukum Islam yang sudah disepakati tersebut. Kemudian lebih lanjut yang menjadi dasar dan landasan dari Kompilasi ini adalah Keputusan Menteri Agama Republik Indonesia tanggal 22 Juli 1991 No. 154 Tahun 1991 tentang pelaksana Instruksi Presiden Republik Indonesia No. 1 Tahun 1991. konsideran keputusan ini menyebutkan:

a. Bahwa Instruksi Presiden Indonesia No. 1 Tahun 1991 tanggal 10 Juni 1991 memerintahkan kepada Menteri Agama untuk menyebarluaskan Kompilasi Hukum Islam untuk digunakan oleh Instansi Pemerintah dan masyarakat yang memerlukannya;

b. Bahwa penyebarluasan Kompilasi Hukum Islam tersebut perlu dilaksanakan dengan sebaik-baiknya dan dengan penuh tanggung jawab;

c. Bahwa oleh karena itu, perlu dikeluarkan Keputusan Menteri Agama Republik Indonesia tentang pelaksanaan Instruksi Presiden Republik Indonesia Nomor 1 Tahun 1991 tanggal 10 Juni $1991^{27}$.

Pengaturan lebih lanjut adalah termuat dalam Surat Edaran Direktur Pembinaan Badan Peradilan Islam atas nama Direktur Jenderal Pembinaan Kelembagaan Agama Islam tanggal 25 Juli 1991 No. 3694/EV/ HK. 003/ AZ/ 91 yang ditujukan kepada Ketua Pengadilan Tinggi Agama dan Ketua Pengadilan Agama di seluruh Indonesia tentang penyebarluasan Instruksi Presiden RI No. 1 Tahun 1991 tanggal 10 Juni 1991. Namun sayangnya di sini juga tidak disebutkan/dilampirkan teks resmi dari kompilasi yang merupakan satu kesatuan dari Instruksi Presiden No. 1 Tahun 1991 yang dimaksud.

Semenjak lahirnya Peradilan Agama, para hakim tidak memiliki buku standar yang dapat dijadikan rujukan yang sama. Maka secara praktis, kasus yang sama dapat lahir dari putusan yang berbeda jika ditangani oleh hakim yang berbeda sehingga tidak ada kepastian hukum. Itulah sebabnya pada tahun 1985 pemerintah memprakarsai proyeksi KHI. Proyek ini diwujudkan dalam bentuk SKB antara Ketua Mahkamah Agung dan Menteri Agama di Yogyakarta. Sasaran

\footnotetext{
${ }^{26}$ Abdurrahman, op.cit, h. 53

${ }^{27}$ Ibid, h. 55-56
} 
proyek KHI ini adalah mempersiapkan rancangan buku hukum dalam bidang perkawinan, pembagian warisan, pengelolaan wakaf, sedekah dan infak. ${ }^{28}$

Dilihat dari tata hukum nasional, KHI dihadapkan pada dua pandangan; pertama, sebagai hukum tidak tertulis seperti yang ditunjukkan oleh penggunaan instrumen hukum berupa Inpres yang tidak termasuk dalam rangkaian tata urutan peraturan perundangan yang menjadi sumber hukum tertulis. Kedua, KHI dapat dikategorikan sebagai hukum tertulis yang menunjukkan bahwa KHI berisi law dan rule yang pada gilirannya terangkat menjadi law. Inpres No. 1 Tahun 1991 dipandang sebagai salah satu produk political Power yang mengalirkan KHI dalam jajaran law. Pada akhirnya masyarakat pemakai KHI yang menguji keberanian pandangan ini sehingga menjadikannya sebagai hukum tertulis. ${ }^{29}$

Menurut Masrani Basran, politik hukum nasional sebagaimana ditetapkan dalam GarisGaris Besar Haluan Negara adalah kodifikasi hukum, dan di mana mungkin unifikasi hukum. Oleh karena kebutuhan yang amat mendesak, maka Mahkamah Agung berpendapat perlunya ditetapkan sasaran yaitu Kompilasi Hukum Islam. Dikatakannya juga bahwa dengan adanya kompilasi hukum tersebut para Hakim Agama akan mempunyai pegangan tentang hukum yang harus diterapkan dan masyarakat akan lebih mantap dalam pengetahuannya tentang hak dan kewajiban menurut hukum-hukum Islam. Selain itu dikemukakannya pula tujuan lain dari Kompilasi Hukum Islam adalah agar masyarakat Islam yang awam dalam hukum dan berbahasa Arab (bahasa-bahasa kitab kuning) dapat pula mengetahui hak dan kewajiban menurut hukum Islam. Terutama hukum-hukum Islam yang dalam Negara kita telah merupakan hukum positif, yaitu hukum-hukum Islam yang telah menjadi kewenangan Peradilan Agama $^{30}$.

Kehadiran KHI cenderung menjadi alternatif terhadap konstatasi yang berpengaruh kuat pada seleksi pengambilan sumber normatif. Lima sumber utama yang dipilih untuk penyusunan KHI yakni: (1) hukum produk legislatif nasional yang telah tertuang dalam perundang-undangan dan peraturan lainnya yang relevan, seperti UU No.22 Tahun 1946 jo UU No.32 Tahun 1954, UU No. 1 Tahun 1974, UU No. 7 Tahun 1989, PP No.9 Tahun 1975, PP No.28 Tahun1977; (2) produk yudisial pengadilan dalam lingkungan peradilan agama, terutama sepanjang yang mengenai masalah waris dengan dukungan pengalaman tafsir hukum mengantisipasi tuntutan di

\footnotetext{
${ }^{28}$ Munawir Sadzali, Peradilan Agama dan Kompilasi Hukum Islam, dalam Mufti AM, Pembaharuan Hukum dalam Kompilasi Hukum Islam di Indonesia, (Manado: Jurnal al-Syir'ah ), h. 73.

${ }^{29}$ Abdul Gani Abdullah, op. cit, h. 64.

${ }^{30}$ Masrani Basran, Kompilasi Hukum Islam, Mimbar Ulama No. 105 ( t. Cet; t.p: t.th, 1986), h. 10
} 
tengah hubungan konflik hukum Islam dengan hukum adat; (3) produk ekspalansi fungsionalisasi ajaran Islam melalui kajian hukum yang dilakukan IAIN dengan pokok bahasan sesuai dengan distribusinya; (4) rekaman pendapat hukum; (5) hasil studi perbandingan d Maroko, Turki, dan Mesir. ${ }^{31}$

Kompilasi Hukum Islam diharapkan dapat menyatukan wawasan hakim Peradilan Agama di Indonesia dalam memecahkan berbagai masalah yang dimajukan kepada mereka. Selain itu, seperti yang dikemukakan oleh almarhum Wasit Aulawi, Kompilasi Hukum Islam ini, mudahmudahan dapat (1) memenuhi asas manfaat dan keadilan berimbang yang terdapat dalam Kompilasi Hukum Islam, (2) mengatasi berbagai masalah khilafiyah (perbedaan pendapat) untuk menjamin kepastian hukum, dan (3) mampu menjamin bahan baku dan berperan aktif dalam pembinaan hukum nasional ${ }^{32}$.

\section{Isi Kompilasi Hukum Islam}

Kompilasi Hukum Islam terdiri atas tiga buku, masing-masing buku I tentang Perkawinan, buku II tentang Kewarisan dan buku III tentang Perwakafan. Pembagian dalam tiga buku ini hanya sekedar pengelompokan bidang hukum yang dibahas yaitu bidang hukum Perkawinan (munakahat), bidang hukum Kewarisan (faraidh) dan bidang hukum perwakafan. Dalam kerangka sistematikanya masing-masing buku terbagi dalam beberapa bab-bab tertentu dan terbagi pula atas beberapa bagian yang selanjutnya dirinci dalam pasal-pasal.

Secara keseluruhan Kompilasi Hukum Islam terdiri atas 229 pasal dengan distribusi yang berbeda-beda untuk masing-masing buku. Porsi yang terbesar adalah pada buku Hukum perkawinan, yakni mulai pasal 1 sampai pasal 170. Kemudian Hukum Kewarisan yang dimulai dari pasal 171 sampai dengan pasal 193, Wasiat dimulai dari pasal 194 sampai pasal 209 dan Hibah dari pasal 210 sampai pasal 214. kemudian yang paling sedikit Hukum Perwakafan yang dimulai dari pasal 215 sampai dengan pasal 227. ditambah pasal ketentuan peralihan dan ketentuan penutup yang masing-masing satu pasal. Perbedaan ini timbul bukan karena ruang lingkup materi yang berbeda, akan tetapi hanya karena intensif dan terurai atau tidaknya pengaturannya masing-masing yang tergantung pada tingkat penggarapannya. Hukum perkawinan karena sudah digarap sampai pada hal-hal yang detail dan hal yang sedemikian dapat

\footnotetext{
${ }^{31}$ Abdul Gani Abdullah, op. cit, h. 66.

${ }^{32}$ Lihat HA Wasit Aulawi, Kompilasi Hukum Islam dalam Sistem Hukum Nasional, ( Pidato Pengukuhan Guru Besar, Jakarta: IAIN Syarif Hidayatullah, 1989), h. 12.
} 
dilakukan mencontoh pada pengaturan yang ada dalam perundang-undangan tentang perkawinan. Sebaliknya karena hukum kewarisan tidak pernah digarap demikian, maka ia hanya muncul secara garis besarnya dan dalam jumlah yang cukup terbatas ${ }^{33}$.

Selain itu pengaturan yang ada dalam Kompilasi Hukum Islam ini khusunya untuk bidang perkawinan tidak lagi hanya terbatas pada hukum substantive saja yang memang seharusnya menjadi porsi dari Kompilasi akan tetapi sudah cukup banyak memberikan pengaturan tentang masalah prosedural atau yang berkenaan dengan cara tatacara pelaksanaan yang seharusnya termasuk dalam porsi perundang-undangan perkawinan. Sebagiannya telah termuat dalam Undang-undangNo. 1 tahun 1974 dan peraturan pelaksanaannya sebagaimana kemudian dilengkapi dengan berbagai Undang-undang seperti Undang-undang No. 7 tahun 1989 tentang Peradilan Agama yang juga memuat beberapa pasal yang berkenaan dengan hukum acara mengenai perceraian. Akibat dimasukannya semua aspek hukum tersebut maka terjadi pembengkakan dalam bidang hukum perkawinan sedang dalam hukum lainnya terasa sangat sedikit.

Ditinjau dari materi dan muatan Kompilasi Hukum Islam ini, khususnya mengenai hukum perkawinan dapat dilihat dari banyaknya terjadi duplikasi dengan apa yang diatur dalam Undangundang No. 1 tahun 1974 dan/atau Peraturan Pemerintah No. 9 tahun 1975 mengingat Kompilasi Hukum Islam ini juga mengatur ketentuan-ketentuan yang bersifat procedural. Namun, kita juga tidak menutup mata banyak hal-hal baru yang kita temukan dalam kompilasi ini.

Istilah perkawinan sebagai istilah Indonesia untuk pernikahan melalui Kompilasi ini sudah dibakukan dalam hukum Indonesia. Mengenai pengertian perkawinan yang dalam hal ini digunakan dalam konteks dasar-dasar perkawinan dirumuskan sedikit berbeda dengan apa yang disepakati dalam Undang-undang No. 1 Tahun 1974. Dalam pasal 2 Kompilasi disebutkan bahwa perkawinan menurut Hukum Islam adalah pernikahan, yaitu akad yang sangat kuat atau miitsaaqan gholiidhan untuk mentaati perintah Allah dan melaksanakannya merupakan ibadah. Kemudian pasal 3 menyebutkan perkawinan bertujuan untuk mewujudkan kehidupan rumah tangga yang sakinah, mawaddah, dan rahmah. Sedangkan dalam pasal 1 Undang-undang No. 1 Tahun 1974 merumuskan perkawinan adalah ikatan lahir batin antara seorang pria dengan

\footnotetext{
${ }^{33}$ Abdurrahman, op. cit, h. 63
} 
seorang wanita sebagai suami istri dengan tujuan membentuk keluarga ( rumah tangga ) yang bahagia dan kekal berdasarkan Ketuhanan Yang Maha Esa ${ }^{34}$.

Dalam pasal 5 disebutkan agar terjaminnya ketertiban perkawinan bagi masyarakat Islam "harus" dicatat. Pencatatan dilakukan oleh Pegawai Pencatat Nikah sebagaimana yang diatur dalam UU No. 22 Tahun 1946 jo. UU No. 32 Tahun 1954. pasal 6 ayat 1 mengulangi pengertian pencatatan dimaksud dalam artian setiap perkawinan "harus" dilangsungkan di hadapan dan di bawah pengawasan Pegawai Pencatat Nikah. Bilamana kita membaca lebih lanjut isi Kompilasi kata "harus" di sini adalah maknanya "wajib" menurut pengertian hukum Islam. Oleh karena perkawinan yang dilakukan di luar pengawasan Pegawai Pencatat Nikah "tidak mempunyai kekuatan hukum,"35.

Sebagaimana yang telah diatur mengenai hukum perkawinan dalam buku 1 mengenai ketentuan umum, maka pada buku hukum kewarisan juga diuraikan mengenai pengertianpengertian umum. Seperti apa itu hukum kewarisan, siapa yang diamksud dengan ahli waris, pewaris, harta warisan, harta peninggalan, wasiat, hibah dan lain-lain.

Persoalan agama menjadi sangat esensial sehingga harus ada penegasan bahwa perbedaan agama akan menghilangkan hak waris, namun hal ini tidak kita temukan dalam Kompilasi ini. Sebagaimana halnya pewaris adalah beragama Islam maka ahli waris pun harus beragama Islam juga. Untuk itu pasal 172 menegaskan tentang indikator untuk menyatakan bahwa seorang itu adalah beragama Islam.

Mengenai siapa yang ahli waris pasal 174 menyebutkannya secara singkat yaitu ahli waris karena hubungan darah dan ahli waris karena hubungan perkawinan. Kemudian disebutkan keutamaan dari masing-masing ahli waris bilamana semua ahli waris ada. Sayangnya di sini tidak disebutkan bagaimana pewarisan dari seorang pewaris yang meninggal dunia tanpa meniggalkan ahli waris sama sekali. Hal ini, , memang ada diatur dalam pasal 191 tetapi mengenai pembagian warisannya. Begitu juga mengenai keutamaan yang sifatnya lebih kasuistik di mana satu ahli waris dapat mendinding (hijab) ahli waris lainnya seharusnya juga dimuat secara lebih rinci di $\operatorname{sini}^{36}$.

\footnotetext{
${ }^{34} \mathrm{Ibid}$, h. 67

${ }^{35}$ Sedangkan dalam pasal 7 ayat (1) Kompilasi Hukum Islam menyebutkan bahwa perkawinan hanya dapat dibuktikan dengan Akta Nikah yang dibuat oleh Pegawai Pencatat Nikah. Dengan demikian, mencatatkan perkawinan adalah merupakan kewajiban bagi mereka yang akan melangsungkan perkawinan.

${ }^{36} \mathrm{Ibid}$, h. 79
} 
Mengenai buku hukum tentang perwakafan, dalam bab ini isinya jauh lebih sedikit bilamana dibandingkan dengan dua bab sebelumnya, sehingga tidak banyak hal yang perlu dikomentari dalam bagian ini. Selain itu materi hukum yang termuat dalam bagian ini juga sedikit berbeda dengan materi hukum yang diatur dalam dua buku terdahulu yang disebut sebagai materi hukum yang bersifat peka, maka persoalan mengenai perwakafan adalah termasuk dalam lapangan hukum yang bersifat sedikit agak netral.

\section{Penutup}

Secara singkat dan global dalam tulisan ini telah dibahas tentang apa dan bagaimana “ Kompilasi Hukum Islam” dan kedudukan serta keberadaannya di Indonesia. Kompilasi Hukum Islam merupakan sebuah kumpulan dari berbagai pendirian dan pendapat hukum yang berkembang dalam dunia pemikiran Islam di Indonesia yang sudah terseleksi dengan baik .

Kompilasi Hukum Islam dibentuk karena adanya kaitan yang sangat erat dengan kondisi hukum Islam di Indonesia selama ini. Hal itu karena belum adanya satu pengertian yang disepakati tentang hukum Islam di Indonesia. Ada berbagai anggapan tentang hukum Islam yang masing-masing melihat dari sudut pandang yang berbeda. Untuk itu dibentuk KHI sebagai tempat untuk menyatukan ide mengenai apa sebenarnya yang dimaksud dengan hukum Islam di Indonesia. Dengan keluarnya Instruksi Presiden No. 1 Tahun 1991 maka disahkanlah KHI sebagai hukum Islam yang berlaku di Indonesia. Yang mana KHI itu sendiri berisi tentang Syariat ( Hukum Allah), Fiqih, Fatwa para MUI dan yurisprudensi.

Kedudukan Kompilasi Hukum Islam di Indonesia telah diakui oleh Negara dengan adanya Instruksi Presiden No. 1 Tahun 1991 tentang Kompilasi Hukum Islam di Indonesia. Oleh karena itu KHI juga sudah menjadi hukum nasional di Indonesia yang berlaku bagi umat Islam dan menjadi rujukan utama oleh Hakim agama di Pengadilan Agama untuk menyelesaikan perkara terhadap orang-orang yang beragama Islam.

Penyusunan dan perumusan serta penyebarluasan KHI dimaksudkan sebagai pengisi kekosongan hokum substansial yang dijadikan acuan dalam pengambilan keputusan hukum di pengadilan dalam lingkungan Peradilan Agama. Berkenaan dengan hal itu, hakim sebagai penegak hukum dan keadilan, merupakan ujung tombak yang akan menerapkan KHI terhadap perkara yang diajukan kepadanya. Dengan demikian, ia dituntut untuk memahami secara lebih dalam dan komprehensif tentang substansi dan misi yang diemban oleh KHI. 


\section{DAFTAR PUSTAKA}

Abdullah Gani Abdul, Pengantar Kompilasi Hukum Islam dalam Tata Hukum Indonesia, Cet. I; Jakarta: Gema Insani Press, 1994

Abdurrahman, Kompilasi Hukum Islam di Indonesia, (Cet. III; Jakarta: CV. Akademika Pressindo, 2001),

Ali Daud Muhammad, Hukum Islam, Pengantar Ilmu Hukum dan Tata Hukum Islam di Indonesia, ( Cet. 11; Jakarta: PT. Raja Grafindo Persada, 2004

Arifin Bustanul, Kompilasi : Fiqih dalam Bahasa Undang-undang, ( Pesantren, No. 2 Vol. II, 1985), h. 28

Aulawi Wasit HA, Kompilasi Hukum Islam dalam Sistem Hukum Nasional, ( Pidato Pengukuhan Guru Besar, Jakarta: IAIN Syarif Hidayatullah, 1989.

Basran Masrani, Kompilasi Hukum Islam, Mimbar Ulama No. 105 ( t. Cet; t.p: t.th, 1986),

Basry Hasan, Perlunya Kompilasi Hukum Islam, ( Mimbar Ulama No. 104 th. X April 1986),

Bisri Hasan Cik, Kompilasi Hukum Islam dalam Sistem Hukum Nasional,( Cet. I; Jakarta: PT. Logos Wacana Ilmu, 1999),

Harahap M. Yahya, Informasi Materi Kompilasi Hukum Islam: Mempositifkan Abstraksi hukum Islam. (Cet. I; Jakarta: CV. Logos Wacana Ilmu, 1999),

Mujieb Abdul M. dkk, Kamus Istilah Fiqih, ( Cet. I; Jakarta: PT. Pustaka Firdaus, 1994),

Rasyid Roihan A, hukum Acara Peradilan Agama, (Cet. VIII; Jakarta: PT Raja Grafindo Persada, 2001).,

Rafiq Ahmad, Pembaharuan Hukum Islam di Indonesia (Cet. I; Yogyakarta: Gema Media, 2001),

Thaib Hasballah, Tajdid Reaktualisasi dan Elastisitas Hukum Islam. Makalah disampaikan pada acara seminar para hakim dan panitera Peradilan Agama se-Sumatra Utara di Medan tanggal 12 Juni 2002, 